\title{
UNDER-AGE MARRIAGE IN PLURALIST ASIA: AN ANALYSIS OF RELIGIOUS AND SECULAR LAWS OF SOUTH ASIAN COUNTRIES
}

\author{
Usha Tandon*
}

\begin{abstract}
In pluralistic and multi-religious Asia, South Asia is a region with a high incidence of under-age marriage amongst the developing countries of the world. The prevalence of early marriage in these countries, however, varies according to the geographical area or the existence of particular ethnic communities residing in that region. While such marriage takes different forms and has various causes, one concern is overriding, i.e., it results in multi-faced violation of the human rights of the child particularly the girl child. It is disheartening to mention that the practice of under-age marriage is prevalent in South Asia, despite the fact that these countries have laws prescribing minimum age of marriage. The customs, however, override the written laws and marriages are performed in gross violation of national laws.
\end{abstract}

Keywords: South Asia, Child marriage, under-age marriage, secular laws, religious laws, personal laws, socio-cultural norms, human rights and women.

* Associate Professor, Faculty of Law, University of Delhi, India, utandon82@yahoo.com. 


\section{INTRODUCTION}

South Asia stands out as a region with a high incidence of underage marriages amongst the developing countries of the world. ${ }^{1}$ According to an analysis of household survey data for 49 developing countries conducted by UNICEF, 48\% of South Asian Females aged 15 to 24 years had married before the age of $18 .{ }^{2}$ However, the practice is not uniform in all the South Asian countries; the practice also varies within the same country in different regions. The exact extent of such marriages is difficult to assess, because many of child marriages are not registered and are not therefore counted as part of any standard data collection system. ${ }^{3}$ During the period 1986-2004, the percentage of child marriage in South Asian region had been ${ }^{4}$ Bangladesh 65\%, Nepal 56\%, India 46\%, Afghanistan 43\%, Pakistan 32\%, and Sri Lanka 14\%. The prevalence of early marriage ${ }^{5}$ in these countries varies according to the geographical area or the existence of particular ethnic communities residing in that region. For example in India, in some States like Rajasthan, Bihar, Uttar Pradesh, Jharkhand and Orissa child marriage is more prevalent, whereas in Kerala it is almost non-existent.

While such marriage takes different forms and has various causes, one concern is overriding, i.e., it results in multi-faced violation of the human rights of the child particularly the girl child. It is disheartening to mention that practice of under-age marriage is prevalent in South Asia, despite the fact that these countries have laws prescribing minimum age of marriage. The customs, however, override the written laws and marriages are performed in gross violation of national laws.

1 See United Nations Children's Fund, The State of the World's Children: Excluded and Invisible, Figure 3.3, 46 (2006).

2 United Nations Children's Fund, Ensuring the Rights of Indigenous Children, Innocenti Digest No. 11, UNICEF, Innocenti Research Centre, Florence, Itlay, 7 (2004).

3 United Nations Children's Fund, Early Marriage: Child Spouses, Innocenti Digest No. 7, UNICEF, Innocenti Research Centre, Florence, Italy, 4 (2001).

$4 \quad$ Supra n. 1 Table 9 at 136.

$5 \quad$ In this paper, the expressions 'underage marriage,' 'child marriage' and 'early marriage’ have been used interchangeably. 
This paper analyzes the laws of South Asian countries relating to age at the time of marriage, the legal status of under-age marriage, the efficiency of such laws; with a detailed critique of religious, customary and secular laws of India. It also studies, briefly, the place of religion in the national legal system of above mentioned countries; the International Human Rights Law relating to age at marriage; the religious, traditional and socio-cultural norms relating to early marriage in their historical context and their relevance in the present day life.

\section{A PARADIGM SHIFT- FROM 'WELFARE' TO 'HUMAN RIGHTS'}

Social reformers in the first part of $20^{\text {th }}$ century were concerned about early marriage for the welfare of women, especially in India, ${ }^{6}$ and influenced the UDHR and other Human Rights Conventions of the 1950s and 1960s. In the later part of $20^{\text {th }}$ century, the interest centered on the behavioral determinants, fuelling rapid population growth, for obvious reasons. However, from a demographic and then from the health perspective, early marriage has been seen primarily as a contributory factor to early child bearing. Early marriage has received scant attention from the modern women's rights and children's rights movement. There has been virtually no attempt to examine the practice of child marriage as a human rights violation in itself. A shift in focus has begun recently only, wherein child marriage has been regarded as violating the rights of the child, particularly girl child. The groundbreaking work of the Forum on Marriage and the Rights of the Women and Girls, in May 2000, is one example of this shift. ${ }^{7}$ The most recent approach about child marriage relates to the human rights dimensions of child marriage within a feminist perspective. $^{8}$

\footnotetext{
$6 \quad$ Janaki Nair, "Prohibited Marriage: State Protection and Child Wife," Indian Sociology, (1995) in United Nations Children’s Fund, supra n. 3 at 2 .

$7 \quad$ Carron Somerset, Early Marriage: Whose Right to Choose? Forum on Marriage and the Rights of Women and Girls, (2000) in United Nations Children's Fund, Ibid at 3.

$8 \quad$ United Nations Children's Fund, Child Marriage and the Law: Legislative Reforms Initiative Paper Series, Division of Policy and
} 
The primary international human rights conventions concerning the young girl's human rights are the Convention on the Elimination of All Forms of Discrimination against Women, 1979 (CEDAW) and the Convention on the Rights of the Child, 1989(CRC). ${ }^{9}$ These conventions manifest the fundamentals of Universal Declaration of Human Rights (UDHR) and reaffirm UDHR's two legally binding covenants, the International Covenant on Civil and Political Rights, 1966 (ICCPR) and International Covenant on Economic, Social and Cultural Rights, 1966 (ICESCR). A number of human rights instruments lay down norms relating to marriage including issues of age, consent, equality within marriage and the personal and property rights of women. ${ }^{10}$ Some of the well

Planning, NY, i, (2008). See also, Jaya Sagade, Child Marriage in IndiaSocio-legal and Human Rights Dimensions, (2005). Article 16(1) of CEDAW prescribes equality for men and women: (a) the same right to enter into marriage; (b) The same right freely to choose a spouse and to enter into marriage only with their free and full consent;... Article 16(2) states; the betrothal and the marriage of a child shall have no legal effect, and all necessary action, including legislation, shall be taken to specify a minimum age for marriage. Virtually every provision of $C R C$ is of some relevance to the issue of early marriage. Among the most pertinent, however are Articles 1, 3, 6, 19, 24, 28, 34, 35 and 36. Article 1 states that a child mean every human being below the age of 18 years unless, under the law applicable to the child, majority is attained earlier. Article 3 prescribes that in all actions concerning children, the interest of the child shall be a primary consideration. Article 6 deals with the maximum support and development of the child. Article 19 guarantees the right to protection from all forms of physical or mental violence, injury or abuse, maltreatment or exploitation, including sexual abuse, while in the care of parents, guardian or any other person. Article 24 emphasize the right to health, and to access to health services and to be protected from harmful traditional practices. Articles 28 and 29 provide right to education on the basis of equal opportunity. Article 34 prescribes the right to protection from all forms of sexual exploitation and sexual abuse. Article 35 guarantees the right to protection from abduction, sale or trafficking and Article 36 gives right to protection from all forms of exploitation prejudicial to any aspect of the child's welfare. Supra n. 3 t 3.

10 Article 16 of Universal Declaration of Human Rights (UDHR) 1948, states (1) Men and women of full age... have the right to marry and 
recognized international human rights of girl violated by underage marriage are discussed below.

When the girl child is given in marriage, her right to equality is violated, as she is discriminated on the basis of age and gender. This violates Article 2(2) of the CRC which places a duty on the State to "take all appropriate measures to ensure that the child is protected against all forms of discrimination... on the basis of... beliefs of the child's parents, legal guardian, or family members.” It also violates Article 2 (e) of CEDAW which protects women from discrimination in both the private and public spheres. ${ }^{11}$ The practice of early marriage of girls also violates the right to equality on the ground of sex as well as gender. It violates the right in both forms of equality-formal as well as substantive. The prohibition against sex discrimination has largely been interpreted to require that like be treated alike or those similarly situated are to be treated equally. ${ }^{12}$ Within this prevailing conception, equality is treated with

found a family. They are entitled to equal rights as to marriage, during marriage, and at its dissolution. (2) Marriage shall be entered into only with the free and full consent of the intending parties. Similar provisions are included in International Covenant on Economic, Social, and Cultural Rights, 1966 and International Covenant on Civil and Political Rights, 1966. Article 1 of Supplementary Convention on the Abolition of Slavery, the Slave Trade and Institutions and Practices Similar to Slavery, 1956 includes in the institutions and practices similar to slavery: Article 1 (c) Any institution or practice whereby: (1) A woman without the right to refuse, is promised or given in marriage on payment of a consideration in money or in kind to her parents, guardian, family... Articles 1,2 and 3 of the Convention on Consent to Marriage, Minimum Age of Marriages, 1964 state: (1) No marriage shall be legally entered into without the full and free consent of both parties, such consent to be expressed by them in person....as prescribed by law. (2) States Parties to the present Convention shall specify a minimum age for marriage ('not less than 15 years' according to the non-binding recommendation accompanying this Convention). No marriage shall be legally entered into by any person under this age, except where a competent authority has granted a dispensation as to age, for serious reasons, in the interests of the intending spouses...(3) All marriages shall be registered by the competent authority. Ibid.

$11 \quad$ United Nations Children's Fund, Supra n. 8 at 17.

$12 \quad$ See Kathleen Mahony, "Canadian Approaches to Equality Rights and Gender Equality in the Court's” Rebecca Cook (ed), Human Rights of Women, 437 (1994). 
sameness. When the two are same, they are to be treated equally. Any difference in treatment to individuals and groups constitutes discrimination. This is a formal equality. The practice of child marriage of girls when looked at from this narrow perspective of formal equality treats them differently from boys of their age and thus discriminates against them on the ground of sex and violates their right to formal equality. The laws that prescribe a lower age of marriage for girls than boys also discriminate on the ground of sex and thereby violate the right to non-discrimination on the ground of sex provided in ICCPR and ICESCR, CEDAW and CRC.

It is not only on the basis of formal equality that the practice of child marriage of girls can be challenged. It violates substantive equality too. The focus of substantive quality is not simply on equal treatment, but rather on the actual impact of the practice on individuals or groups. The focus is not on sexual discrimination but on gender discrimination. The focus is not on sameness or difference, but rater on disadvantage. The central inquiry of substantive equality approach is whether the practice in question contributes to the disadvantage. Accordingly, the discrimination consists of treatment that further disadvantages a group that has historically and socially experienced systematic oppression..$^{13}$ The practice of child marriage usually victimizes girl children. Girls are perceived as burdens by their parents. Child marriage of their daughters relieves them of the responsibilities attached to raising a girl. At the same time, as the girl's parents are relieved of their burden, the groom's parents also benefit because they gain an unpaid slave and often a dowry.

Article 16.1 UDHR proclaims that women of full age have the right to marry and found a family. Article 23.2 of ICCPR guarantees the right of men and women of marriageable age to marry and found a family. Article 16 (2) of CEDAW declares that the marriage of a child shall have no legal effect. The terms full age, marriageable age and child are not defined by the respective international instruments. Article 1 of CRC defines 'child' as every human being below the age of 18 years. By referring to this definition the minimum marriageable age, as per international law standards, could be interpreted as 18 years. Therefore, the Constitution" in Ratna Kapur (ed.) Feminist Terrains in Legal Domains, 61 at 64 (1996). 
it could be argued very well that the right of young girls to marry at a 'marriageable age,' 'full age' is violated when they are married off before attaining the age of 18 years. ${ }^{14}$

Further, girls married at an early age are forced to enter into motherhood and family responsibilities for which they are unprepared. They do not have the capacity to negotiate with their spouse. They lack the information and means to plan their family. This results in the denial of their right to found a family.

The right to reproductive health is an essential element of a woman's general right to health. Reproductive health rights have been accepted as a part of human rights in various international instruments. Since the United Nations Conference in Cairo in $1994^{15}$ and in Beijing (1995). ${ }^{16}$ there has been increasing recognition by the international community of a number of women's rights in the area of reproductive health. The ICPD program of Action declares that reproductive health is the state of complete physical, social and mental well being of not just merely the absence of disease or infirmity in all maters relating to the reproductive system and to its functions and processes. Early marriage and early childbirth are linked to high rate of pregnancy related complications including risk to life, miscarriage, anaemia, obstructed laor, visico-or-recto-vaginal fistulas, incontinence, stillbirth, or risk to the life of new born. ${ }^{17}$ Thus child marriage leads to a vicious circle of early pregnancy, malnutrition and maternal mortality. ${ }^{18}$ Failure on the part of State to prohibit child marriage, exposes the child brides to these health risks and thereby results in the violation of their right to sexual and reproductive health. ${ }^{19}$

Jaya Sagade, supra n. 8 at 149.

United Nations, Population Development, Program of Action adopted at the International Conference on Population and Development, Cairo, Vol. 1, (5-13 Sep) (1994).

United Nations, Platform for Action: Fourth World Conference on Women, (4-15 Sep) (1995).

CESCR, General Comment 14, The Right to the Highest Standard of Health: E/C.12.2000/4, Para 8, 4 July 2000.

Government of India, Department of Women and Child Development, Commitment to the Child-National Plan of Action for the SAARC Decade of the Girl Child, 2 (1991-2000). Jaya Sagade, supra n. 8 at 181. 
Child marriage, further, violates the girl's right to development. In General Comment 21 on Equality in Marriage and Family Relations, CEDAW provides that the responsibilities that women have to bear and raise children affect their right to access education, employment, and other activities related to their personal development. ${ }^{20}$ Early marriage and child bearing impede the girl's educational and employment opportunities drastically. ${ }^{21}$ Girls are unable to pursue avenues leading to their overall personality development. Sometimes child marriage can be used as a disguise and may culminate into trafficking of the girl child across the national borders for prostitution. ${ }^{22}$

\section{REGIONAL COMMITMENTS}

All South Asian countries have ratified the conventions related to the rights of the child, their protection and well being (some countries have ratified these conventions with few reservations) like CEDAW (Convention on the Elimination of All forms of Discrimination Against Women), CCMMAMRM (Convention on Consent to Marriage, Minimum Age for Marriage and Registration of Marriages), Beijing Platform for Action etc. With a view to draw attention to the condition of children and to improve their lot, SAARC countries declared 1990 as the year of the girl child, 1991-2000 as the decade of the Girl Child and the current decade 2001-2010 as the decade of the Rights of the Child. All the countries reaffirmed their commitment to improve the condition of children and to raise the status of the girl child. They recognized that the problems of these children like discrimination against the girl child and early marriages are inextricably linked to the prevailing socio-economic conditions and called for a holistic approach to address them. All the member states expressed their determination to protect the girls from exploitation and to promote their welfare.

\footnotetext{
$20 \quad$ Also see Article 26 UDHR; Article 13 and 14 ICESCR.

21 Government of India, Department of Women and Child Development, Fourth World Conference on Women, Bejing 1995-Country Report, 19(1995).

22 United Nations Children's Fund, The Best Interest of Child: Towards A Synthesis of Rights and Cultural Values, 19 (1996).
} 
In 2002, all South Asian countries adopted the SAARC Convention on Regional Arrangement for the Protection of Child in South Asia. ${ }^{23}$ This Convention makes it necessary for the States to ensure that National laws protect the children from all forms of discrimination abuse, neglect, exploitation, torture and degrading treatment. The regional Convention highlights the relevant international instruments for children with particular reference to the commitment of the State parties to the UN Convention on the Rights of the Child. It calls for the need of concerted regional actions for securing their rights which are crucial for the progress and development of children and cooperation among State parties to work towards progress and development of the full potential of the South Asian child taking into account their changing needs.

Another important instrument is the SAARC Social Charter, $2004^{24}$ signed at the twelfth SAARC summit held in Islamabad. This Charter has given a boost to the social agenda developed by SAARC countries over the years. It emphasizes on preparing action plans on a broad range of subjects with regional dimension which have to be achieved across the region, for promotion of the rights and the well being of the child.

\section{NATIONAL LEGAL DISCOURSE: SOUTH ASIAN COUNTRIES}

In Sri Lanka, several legal systems govern the law of family relations. The Constitution of Sri Lanka adopted in $1978^{25}$ guarantees

$23 \quad$ SAARC Convention on Regional Arrangements for the Promotion of Child Welfare in South Asia, available at www.unicri.it/.../Saarcconvention-on_regional_arrangements.pdf visited on Jan.2,2010.

24 Social Charter available at www.saarc-sec.org/main.php?id=13 visited on Jan.2, 2010.

25 Constitution of Sri Lanka, 1978, Articles 10 and 14.

Further, the Wills Ordinance which lays down the law regarding wills is applicable to any one and there are no prohibitions on the types of bequests that may be made by a will in Sri Lanka. see Ramani Muttettuwegama, "Equality in the Context of Women living under Parallel Legal Systems: The Problem of Sri Lanka,” available at www.Virtual Library: Kandyan Weddings, see also www.lankalibrary. com, visited on Jan. 3, 2010. 
protection of freedom of religion to all its citizens made up of several ethnic and religious groups. The General law (a combination of Roman Dutch and English law) is the main system applicable to every one except if they are governed by the personal laws. There are three other parallel systems of personal laws in Sri Lanka, i.e., Kandyan Law, The Thesavalamai and the Muslim Law. These laws are grounded in ancient customary practices and/or religion. Thus the law relating to marriage consists of General law, the Personal laws and the Customary law. Tamils are governed by the General law in most of their marriage-related matters, whereas Kandyans Sinhalese can choose to be governed by the General law or their Customary laws. Muslim are governed by Muslim Personal Law. ${ }^{26}$

$26 \quad$ Kandyan. The Kandyan law cites as its source the laws and customs of the Kandyan Kingdom (the last area of Sri Lanka to be colonised) and is applicable to all Kandyan Sinhalese. A "Kandyan Sinhalese" is one whose parents can trace their lineage to being residents of the Kandyan Provinces during the Kandyan Kingdom and include those who currently do not reside in "Kandyan areas." Thus not all people domiciled within the Kandyan provinces fall within the definition of a "Kandyan Sinhalese." The areas of Kandyan law that are currently retained in Sri Lanka relate to marriage and divorce and intestate succession. All Kandyans have the option of choosing whether they marry under the Marriage and Divorce (Kandyan) Act [M \&D (K)A] and, thus be governed by the Kandyan laws or the General Marriages Ordinance in which case, they would be governed by the Roman Dutch law. In the case of intestate succession, a Kandyan person is governed by the Kandyan Law by virtue of the Kandyan Law Ordinance (KL) as well as the Matrimonial Rights and Inheritance Ordinance. Some areas of the Kandyan laws on adoption are also applicable here. In all other areas such as maintenance and custody the general law applies.

Thesavalamai. The Thesavalamai is part of some ancient customs of Tamils in Sri Lanka and India. In Sri Lanka the law is applicable to the "Malabar inhabitants of the Jaffna Peninsular" and the persons governed by the law include those who do not reside in Jaffna any longer. The only areas of the Thesavalamai personal laws that are now applicable are matrimonial rights with respect to property and intestate succession. These are governed by the Matrimonial Rights and Inheritance (Jaffna) Ordinance [MR \&I (J)O]. In all other areas, the general law applies. 
Muslim. The Muslim special laws are applicable to people who follow Islam. In all areas of family the Muslim law applies and, unlike with Kandyans, in the event of marriages between Muslims, they do not have the option of marrying under the General law at all. Marriage, divorce and all other related areas are governed by the Marriage and Divorce (Muslim) Act [M\&D(M)A] No. 13 of 1951 and the subsequent amendments. The act states that the law is applicable to marriages and divorces and other matters connected herewith, of Muslim inhabitants of Sri Lanka. This Act covers a range of areas and clarifies the situation of women belonging to the Shafi sect. The Act also goes on to state that the status and rights and obligations of the parties shall be determined according to the Muslim law governing the sect to which the parties belong and that non/registration of marriage alone will not in/validate a marriage or divorce which would otherwise have been valid/invalid according to the law of the sect. The areas of intestate succession and donations are dealt with by the Muslim Intestate Succession Ordinance No.10 of 1931 (MISO) that is applicable to the intestacy of and donations made by Muslims either domiciled or owning immovable property in Sri Lanka. The Act merely states that the law applicable will be that of the relevant sect and it is necessary to examine the Muslim law itself in order to ascertain its contents. It is important to note that both Acts make provisions for the laws governing each sect that the person in question belongs to prevail, notwithstanding anything to contrary in the Act itself.

General Law. The term "General” is misleading because it is more a catchall law. Every area of family laws is covered by some aspect of general law. The area of marriage including the age of marriage, the procedure for a marriage, the registration of marriage and its dissolution either by divorce or through a judicial separation is governed by the Civil Procedure Code (CPC) and the General Marriage Ordinance (GMO). The GMO is applicable to all marriages except those between Muslims. It also contains express provisions regarding the recognition of traditional forms of marriage as being valid. The law on the matrimonial rights of married persons with regard to property and intestate succession is contained in the Matrimonial Rights and Inheritance Ordinance (MR \& IO) read together with the Married Women's Property Act (MWPA). These acts are not applicable to Kandyans, Muslims or people governed by the Thesavalamai. The law on adoption is contained in the Adoption Act as amended. On the face of it, the Act is applicable to all communities. In terms of intestate succession, however, its applicability differs according to the community. The general law on maintenance is contained in the Maintenance Ordinance. This Ordinance has been amended recently to shift away from the old 
In 1995, sweeping reforms were made in a number of laws which were further enhanced in 1998. The General Marriage Ordinance and the Kandyan Marriage and Divorce Act were also amended. These amendments increased the minimum age of marriage to 18 years for boys as well as for the girls. The minimum age of marriage had hitherto remained 12 years for girls and 16 years for boys.

Under the general law and the Kandyan Law, minimum age of marriage is now 18 years for both males and females. However, under the Muslim law, there is no minimum age although the registration of a marriage of a girl under 12 years of age is prohibited unless authorized by the Quazi. Although there are very few recorded instances of children under the age of twelve being married under the Muslim law, the anomaly could have far reaching impact on the lives of Muslim girls. Under the Penal Code of Sri Lanka, until 1995, the general age of consent for sexual relations was 12 years. In 1995, the Penal Code was amended and the age of statutory rape was raised to 16 years unless the person happens to be the perpetrator's wife and they are not judicially separated ${ }^{27}$

In Sri Lanka, after 1995 marriages of non-Muslims below the age of 18 years are void. ${ }^{28}$ It cannot be validated even by the parental consent. These amendments were brought about with the objective of preventing child marriages and child pregnancies that are detrimental to the health and the well-being of the children.

Nepalese legal system is a mix of Hindu philosophy, Common and Civil Legal System. The Civil Code of 1853 was totally based on

concept of indigence and need to a general right of persons to maintenance. However, since the 1951 Marriage and Divorce (Muslim) Act, the Maintenance Ordinance is not applicable to people who marry under it. Further, the Wills Ordinance which lays down the law regarding wills is applicable to any one and there are no prohibitions on the types of bequests that may be made by a will in Sri Lanka. see Ramani Muttettuwegama, "Equality in the Context of Women living under Parallel Legal Systems: The Problem of Sri Lanka,” available at www.Virtual Library: Kandyan Weddings, see also www.lankalibrary. com, visited on Jan. 3, 2010.

$27 \quad$ See Penal Code (Amendment) Act. Nos. 22 of 1995 and 29 of 1998; Code of Criminal procedure (Amendment) Act. No. 28 of 1998; Judicature (Amendment) Act. No. 27 of 1998; Evidence (Special Provisions) Act of 1999.

$28 \quad$ United Nations Children’s Fund, supra n. 8 at 31. 
religious values and prevailing custom of that time. It was the first codified law of Nepal which was later repealed by Civil Code $1963 .{ }^{29}$ The Code fixes the legal age for marriage of girls at 16 and makes child marriage illegal. A girl can marry after the age of 16 years with the consent of her parents or guardians, and at 18 she can marry without their consent. The corresponding ages for men are 18 and 21 years.

In Nepal the violation of marriage age law results in penal consequences. The penalty varies depending on the age of the girl. This includes both prison sentence and fine. The fee collected is to be returned over to the girl involved. For any person responsible for arranging the marriage of a girl under 10 years of age, the penalty is from 3 months to 3 years imprisonment, plus a fine of Rs. 500 to Rs. 5,000. ${ }^{30}$ When the age of the girl is above 10 years but under 14 years, those responsible for her marriage are liable to imprisonment up to one year and a fine of Rs. 2000. If the girl is between the ages of 14 to 16 years, the punishment is up to 3 months imprisonment and a fine of Rs 1,000. Anyone responsible for arranging the marriage of a girl in the age group 16-18 years without her parent's consent is liable for a fine of up to Rs. 500. When the girl is above 14 and under 16, the penalty is either imprisonment up to 15 days or a fine of up to Rs 300. Anyone responsible for arranging the marriage of a girl under 18 and boys under 21 without the consent of their respective parents are liable to be charged a fine up to Rs. $300 .{ }^{31}$

According to Bhutanese Marriage Act, 1980, the minimum age of eligibility for marriage was 16 years for women and 18 years for men. After 1996 amendment, it is 18 years for both boys and girls. ${ }^{32}$ The registration of marriage is compulsory. ${ }^{33}$ The certificate for marriage registration can not be issued to anyone who had not attained the legal age at the time of the marriage. In Bhutan, marriage of a person below

$29 \quad$ Legal System of Nepal available at http://lawandsocietynepal.com/ aboutnepal.html visited on Feb. 27, 2010.

30 See Rupa Dhital, Child Marriage in Nepal, available at http:// www.cwin.org.np/resources/papers_articles/child_marriage.htm visited on Feb. 27, 2010.

31 Ibid.

32 Marriage Act, 1980, Kha 1-2 available at www.bhutanica.org/ index.php?title=Marraige_Act_1980 visited on Feb. 26, 2010.

33 Ibid, Ks 1-3 to 1-6. 
the prescribed age is liable for penal action. Persons responsible for arranging such marriages are also punished. In Bhutan though registration of marriage is compulsory by law, yet both boys and the girls can engage in marriage as early as fifteen years taking advantage of the Common Law Marriage Act.

Under section 21 of the National law of Maldives the minimum age of marriage ${ }^{34}$ for girls as well as boys is 18 years, unless the marriage registrar determines that there are special circumstances for the couple to get married earlier. The customary law permits the girls to get married at the age of 15 years. In Maldives, particularly in the outlying atolls, marriages below the legal age of 18 years take place without the certificate from the registrar due to the customary law. However the number of such marriages is fast declining. There is an unwritten law in Maldives that marriage before the age of 15 should be discouraged and the parents are advised to discourage marriage before the age of 16 . In Maldives, despite traditional culture, the mean age at marriage for women has increased. The number of early marriages is constantly declining in this island. Improved access to secondary education and more employment opportunities appear to have a positive impact on the age at marriage. The singulate mean age of marriage in Male where there are more opportunities for secondary education and employment, is found to be higher than that of the national average, both for the males as well as females. The singulate mean age of marriage in Male is estimated to be 26.35 years for males and 23.29 years for females. ${ }^{35}$

The legal age of marriage in Bangladesh, according to Child Marriage Restraint Act, 1929 is 18 years for girls and 21 years for boys. ${ }^{36}$

\footnotetext{
34 www.1.umn/humanrts/cedaw/maldives2001html; visited on Feb 26, 2010.

35 UNRC, Reproductive and Sexual Health of Adolescents in Maldives, 19(Feb. 2003).

36 Various personal laws in Bangladesh that aim to achieve equality for women are: Family law ordinance of 1961, Family Courts Ordinance of 1965, Dowry prohibition Act of 1980, Child marriage Restraint to Women (Deterrent Punishment) Ordinance of 1983, The Muslim Family Laws (Amendment) Ordinance of 1982 and 1985. See Fifth Periodic Report of Bangladesh submitted under 18 of CEDAW (2003) available at www.un.org/womenwatch/daw/cedaw/reports.htm visited on Feb 26, 2010.
} 
Under the Registration of Marriage Act, the registration of marriage is compulsory. Religious laws permit marriage soon after puberty or even at an earlier age by parental consent. In Bangladesh too, there are penal sanctions for contracting under age marriage or failure to register them, yet underage marriages are not considered invalid. Marriage Registration Act prescribes penal sanctions for those who violate the mandatory registration requirements of marriage, but failure to register a marriage does not invalidate the marriage.

Under the Child Marriage Restraint Act, 1929 of Pakistan, the legal age for marriage of girls is 16 years and for boys 18 years. Under the Muslim Family Law Ordinance, too, a girl must have attained the age of 16 years and a boy must have attained the age of 18 years. According to Hudood Ordinance 1979, a girl becomes an adult on attaining puberty and can be married any time after that. Although the law does not permit the marriage of a girl below the age of 16 years, if any girl below the age of 16 years marries in violation of that law, the marriage itself does not become invalid, although the adult husband contracting the marriage or the persons who have solemnized the marriage may be held criminally liable. ${ }^{37}$ If the marriage of an underage girl is performed by her guardian she can repudiate the marriage on attaining puberty. This provision of Muslim law is called the "Option of Puberty." It is incorporated in section 2 (vii) of Dissolution of Muslim Marriage Act, 1939 which offers an additional ground to a girl on the basis of which she can have her marriage dissolved.

\section{INDIAN LEGAL DISCOURSE}

\section{Secular Laws \\ Indian Penal code}

In India, universal and early marriage has been prevalent for a long time. All religion based personal laws governing Hindus, Muslims, Sikhs, Jains and Buddhists were believed to allow marriage of both sexes at a tender age. At the time the Indian Penal Code was enacted in 1860, an effort was made to impose penal sanction against the consummation 
of marriage where the brides were very young. It provided that consummation of marriage with a wife below the age of 10 years would entail the prescribed punishment. ${ }^{38}$ In 1890, this age for legal consummation of marriage was raised to 12 years, ${ }^{39}$ in 1925 it was further raised to 13 years. ${ }^{40}$ In 1926, Hari Singh Gour introduced a Bill for a further amendment in the Indian Penal Code in order to raise the age of cohabitation to 14 Years. The social reformers of that time realized that it was better to prescribe the age of marriage rather than the age of consent (for consummation of marriage) raised by law. The provisions relating to marital rape introduced in the Code did not solve the problem of infant widows who lost their grooms before consummation. And the number of such unfortunate victims of social custom was constantly on the increase. In February 1927, Rai Saheb Harbilas Sarda introduced a Bill (popularly known as Sarda Bill) to restrain the solemnization of child marriage among Hindus by declaring such marriages invalid. The Bill was later referred to a select committee which made it a secular Act and transformed it into a penal statute.

While Hari Singh Gour's Bill for amendment of Indian Penal Code and the Sarda Bill were pending in the legislative assembly, in 1928 the Government appointed an Age of Consent Committee (also known as Joshi committee)to examine the entire perspective of Gour's Penal Code (Amendment) Bill. The Joshi Committee submitted its report in 1929. It suggested that the age of cohabitation under the Indian Penal Code be raised to 15 years and also made several other recommendations in that regard. ${ }^{41}$ It arrived at a definite conclusion that it was easier to postpone the marriage of a minor than to prevent consummation after marriage. With respect to the problem of child-widows, the Committee observed that if marriage is deferred to a given age, many girls below that age will be automatically saved from the terrible risk of early widowhood. ${ }^{42}$ The Committee finally recommended that in order to deal most effectively with the evil of early marriage and early consummation,

\footnotetext{
38 Indian Penal Code, 1860, SS., 375-376 (original version).

$39 \quad$ Ibid., (1891 version).

$40 \quad$ Ibid., (1925 version), Tahir Mahmood, "Marriage Age in India and Abroad- A Comparative Conspectus" 22 JILI, 38 at 40.

41 Government of India, Report of the Age of Consent Committee, 102, (1929).

42 Ibid., at 171.
} 
a law be enacted fixing the minimum age of marriage of girls at 14 years. The Committee also recommended that 'subject to any provision of the personal law for the time being in force, the validity of a marriage held in contravention of the proposed marriage-age law should be left unaffected.' ${ }^{43}$ The Select Committee to which Sarda Bill had been referred had already submitted its report. ${ }^{44}$ That Committee too recommended that validity of minor's marriage be kept out of the scope of the proposed Act which should only lay down penalties for such marriage. After prolonged debates, the Sarda Bill was finally enacted as an exclusively penal law. It was officially known as the Child Marriage Restraint Act, and received Governor-General's assent on $1^{\text {st }}$ October 1929.45

\section{Child Marriage Restraint Act, 1929}

This Act was enforced throughout British India from $1^{\text {st }}$ April 1930. The Act defined 'child' as a person, if male, under 18 years of age and, if female, under 14 years of age. Every person, male or female, below the age of 18 years was described by the Act as 'minor.' 'Child marriage' under the Act was defined as every marriage to which either of the contracting party is a child. The Act declared every child marriage to be an offence for which the following persons could be punishable: one who contracted a child marriage provided he has completed the age of 18 years; guardian who promoted or permitted the child marriage; any one who knowingly performed, conducted or directed a child marriage. Grooms in the age-group of 18-21were to be punished only with fine. The same was true of women found guilty of any offence relating to child marriage. In no case, it is notable, was the child (as defined in the Act) itself to be punished for contracting a marriage. ${ }^{46}$ Soon after the

\footnotetext{
$43 \quad$ Ibid., at 180-81.

$44 \quad$ See Government of India, Gazette of India, Part V, 111, 165 (1928).

45 The Sarda Act of 1929 was not, however the first penal law of marriageage to be promulgated in the subcontinent. Outside British India, laws of that nature already existed before Sarda Act. For details see Tahir Mahmood, supra n. 40 at 45-48.

46 See sections 2-10 of Child Marriage Restraint Act, 1929 (original version), Tahir Mahmood, ibid at 48.
} 
enforcement of the Act, a controversy arose among High Courts as to the power of the Court to prohibit a proposed child marriage by means of an injunction. To resolve the controversy the Child Marriage Restraint (Amendment) Act, 1938 introduced a provision specifically empowering the courts to issue an injunction prohibiting a child marriage arranged or about to be solemnized. Violation of such an injunction was declared to be an offence punishable under the Act. ${ }^{47}$ In 1949, the Act was amended by another Child Marriage Restraint (Amendment) Act which has raised the age of girls from 14 to 15 years under the definition of 'child.' The Amending Act of 1949 also enhanced the penalties for various offenders. ${ }^{48}$ The Sarda Act, unlike the native States never restricted the marriage of minor girls with old men. Nothing in the Act ever provided or suggested that a marriage in violation of its provisions would be void, voidable or invalid. This important issue was left to be decided by various personal laws.

Another amendment to the Act came in 1978, when Child Marriage Restraint (Amendment) Act, 1978 amended the definition of 'child' to mean male below the age of 21 years and a female below the age of 18 years. ${ }^{49}$ Further, the 1978 Amendment has added a new provision to the Act, which made offences under the Act partly cognizable. ${ }^{50}$ Since the Act was silent on the validity or invalidity of child marriage, the Indian judiciary took the view that Child Marriage Restraint Act aimed at and dealt with the restraint of the performance of the marriage, it had nothing to do with the validity of the marriage. The courts have categorically stated that the question of validity or invalidity of the marriage is beyond the scope of the Child Marriage Restraint Act. ${ }^{51}$

\footnotetext{
$47 \quad$ S. 12 added by Act XIX of 1938.

$48 \quad$ Act XLI of 1949.

49

This time the main concern for raising the age of marriage was the population problem of the country which had become acute by that time. Tahir Mahmood, supra n. 40 at 50.

$50 \quad$ Child Marriage Restraint Act, 1929, s. 7.

$51 \quad$ See e.g. Munshi Ram v. Emperor, AIR 1936 All 11; Sivanandy v. Bhagavathyamma, AIR 1962 Mad 400; Birupakashya Das v. Kunju Behari, AIR 1961 Ori 104.
} 


\section{Prohibition of Child Marriage Act, 2006}

The Prohibition of Child Marriage Act, 2006 (hereinafter referred as PCMA) has repealed the Child Marriage Restraint Act, 1929. Since long there has been a growing demand for making the provisions of 1929 Act more effective. The National Commission for Women ${ }^{52}$ recommended inter alia that the Government should appoint child marriage prevention officers; the punishment provided under the Act should be made more stringent; marriages performed in contravention of the Act should be made void and the offences under the Act should be made cognizable. The National Human Rights Commission ${ }^{53}$ made recommendations for comprehensive amendments to the 1929 Act. To give effect to the recommendations of the Commissions, the Central Government instead of amending the Child Marriage Restraint Act, 1929 repealed it and passed new Act entitled Prohibition of Child Marriage Act, 2006, which came into force on January 10, 2007. ${ }^{54}$ PCMA defines 'child' as a person who, if a male has not completed 21 years of age and if a female has not completed 18 years of age. ${ }^{55}$ 'Child marriage' means a marriage to which either of the contracting party is a child. ${ }^{56}$ Section 3 of the Act makes child marriage voidable at the option of the contracting party who was a child at the time of marriage. The petition for the nullity of marriage may be filed at any time but before the child filing the petition completes two years of attaining majority ${ }^{57}$ Provision is made for the maintenance and residence of the female contracting party to the marriage until her remarriage. ${ }^{58}$ The Act also makes a provision for the custody and maintenance of children of child marriage. ${ }^{59}$

Section 12 declares the marriage of a minor child (emphasis added) to be void under three circumstances: where the child being a minor (i) is taken or enticed out of the keeping of the lawful guardian; or

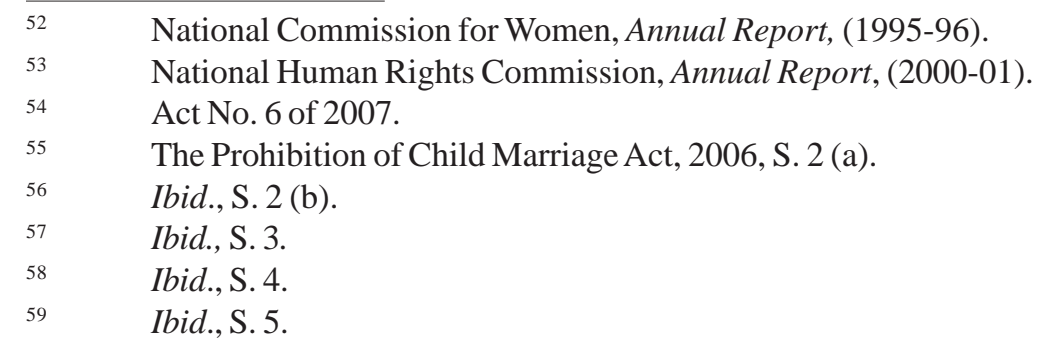


(ii) by force compelled, or by any deceitful means induced to go from any place; or (iii) is sold for the purpose of marriage and made to go through a form of marriage or if the minor is married after which the minor is sold or trafficked or used for immoral purposes. In Aminder Kaur v State of Punjab ${ }^{60}$ which is a case of run away marriage, the Punjab and Haryana High Court ruled the marriage of 16 years old girl, solemnized as per Hindu rites, to be void under section 12 (a) of PCMA, as she was enticed away from the lawful keeping of a guardian by her alleged husband.

Section 14 of the Act provides another ground for making child marriage as void ab initio i.e where it is solemnized in contravention of an injunction order passed by the court. The Act confers the status of legitimacy on the children born of child marriage ${ }^{61}$ All punishments for contracting child marriage have been enhanced. ${ }^{62}$ It is worth noting that no woman can be punished with imprisonment. ${ }^{63}$ The Act also makes all offences under it cognizable and non-bailable. ${ }^{64}$ One of the special features of the Act is the appointment of Child Marriage Prohibition Officers by the State Government who have been empowered to prevent and prosecute the solemnization of child marriage and to create awareness on the problem. ${ }^{65}$ Special powers have been given to the District magistrate to prevent the solemnization of mass child marriages on certain days such as Akhaya trutiya by employing appropriate measures and using minimum force required. ${ }^{66}$

$60 \quad$ In the Punjab and Haryana High Court at Chandigarh CRM-M 29790 of 2009 (O\&M) decided on Nov. 27, 2009, available at www. indiankanoon.org/doc/942424/ visited on March 19, 2010. see also Kammu v State of Haryana, (CRP No. 623 of 2009 (O\&M) decided on Feb. 16, 2010 available at www.indiankanoon.org/doc/1725622/ visited on March 19, 2010.

61 Ibid., S. 6.

62 Ibid., SS 9-11.

63 Ibid., proviso to S 11(1).

$64 \quad$ Ibid., S. 15.

65 Ibid., S. 16.

$66 \quad$ Ibid., S. 13, Sub SS 3 \& 4. 


\section{Criticism of The Prohibition of Child Marriage Act, 2006}

The Prohibition of Child Marriage Act, 2006 is definitely an improvement over the Sarda Act of 1929 in the following respects:-

1. For the first time, in the history of Indian law the marriage of a minor child is declared to be null and void by the central legislation. It needs to be emphasized, however, that section 12 of PCMA does not, make 'child marriage' to be a void marriage. It makes provision for the marriage of minor child (emphasis added) to be void on specific grounds. Though every minor is a child under PCMA, vice-versa is not true. A boy of 19 years, for example is not minor but he is child within the meaning of PCMA. However a girl of 19 years is both major as well as adult. Looking to the nature of three grounds mentioned in section 12 of PCMA, which are also criminal offences under the Penal Code and also to the vulnerability of girls to these offensive practices, this provision incorporates the substantive model of equality. However, it would have been better if the legislature had widened the scope of void marriage to include any violation of the Act.

2. In case of annulled voidable marriage, court is empowered to make an order requiring the contracting party or his guardian to pay maintenance and make provision for the residence of the female contracting party till her remarriage. Since child marriage has disproportionately negative impact on the girl child, section 4 of the Act incorporates the human rights dimensions of child marriage within a feminist perspective.

3. All punishments under the Act have been enhanced. However no woman shall be punishable with imprisonment. Sections 11 and 13 of PCMA are other examples of gender sensitivity of Indian Legislature.

4. Offences under PCMA are cognizable for the purpose of investigation and for other purposes. An offence under the Act is also non- bailable. This conveys the seriousness of legislature to combat child marriage which was lacking under the old Sarda Act of 1929. 
5. For the proper implementation of the Act, it makes provision for the appointment of Child Marriage Prohibition Officers, whose duties have also been listed under the Act. They can be invested with such powers of a police officer as may be specified. For preventing the solemnization of mass marriages on certain auspicious days, the District Magistrate is regarded as the Child Marriage Prohibition Officer with all necessary powers. This provision was totally absent under the Sarda Act. The inclusion of provisions with respect to the implementation of the Act and monitoring of child marriage makes PCMA a meaningful legislation.

The Prohibition of Child Marriage Act, 2006 however, is also a classic case of poor draftsmanship. The Act is full of anomalies. Some of them are mentioned here:-

1. Section 6 of PCMA confers the status of legitimacy on the children born of child marriage which has been annulled by a decree of nullity under section 3 of the Act. It may be noted that a marriage may be annulled by a decree of nullity under Sections 12 and 14 of the Act, which make the marriage in contravention of their provisions as null and void. The children born of child marriage annulled under these provisions have not been legitimized. The legislature should have deleted the words 'under section 3' in section 6 to widen the scope of legitimacy of children.

2. Section 4 of the Act deals with the provision for maintenance and residence to female contacting party to child marriage. The benefit of maintenance and residence has only been provided to the girl who had been a party to annulled voidable marriage under section 3 of the Act. The beneficial provision has not been extended to girls who had been party to void marriage under sections 12 and 14 .

3. Drafting of Section 12 suffers from lacunae. Clauses (a) and (b) of section 12 are simply incomplete. They do not make any reference to 'marriage'. The opening part of section 12 also does not make any reference to 'marriage.' Only Clause (c) of Section 12 mentions 'marriage' of a minor which has been 
declared null and void. ${ }^{67}$ It should be amended to include the word 'child marriage' in the opening part of section 12.

4. Section 5 provides for the custody and maintenance of children of child marriages. The way section 5 has been drafted is the height of ill framed legislation. It does not make any reference to Section 3 or Sections 12 and 14 of the Act. So, if marriage has not been annulled under section 3 or is not covered by sections 12 and 14, where is the need making any provision for the legislature for the custody and maintenance of children of child marriage?

5. Section 20 PCMA reminds one of the old British jingle. ${ }^{68}$ It provides for the amendment of Hindu Marriage Act, 1955 to enhance the punishment under Section 18 clause (a). Surprisingly, no provision is made under section 20 for the amendment of Sections 11, 12 and 13 (2) (iv) of HMA. Consequently even after passing the PCMA the under-age marriage under HMA is neither void nor voidable. It is perfectly valid though punishable and furnishes a ground of divorce to the girl under Section 13 (2) (iv). These provisions of HMA should have been suitably amended in view of the provisions of PCMA.

S. 12. Marriage of a minor child to be void in certain circumstances - Where a child, being a minor-

(a) is taken or enticed out of the keeping of the lawful guardian; or

(b) by force compelled, or by any deceitful means induced to go from any place; or

is sold for the purpose of marriage; and made to go through a form of marriage or if the minor is married after which the minor is sold or trafficked or used for immoral purposes' such marriage shall be null and void.

$68 \quad$ "I am the parliamentary draftsman. I compose the country’s laws. And of half of the litigation, I am undoubtedly the cause." Palace Administrative Board v. RVB Thampuran, AIR 1980 SC 1187 at 1195 in G.P. Singh, Principles of Statutory Interpretation, 23 (1999). 


\section{The Indian Majority Act, 1875}

The Indian Majority Act, 1875 prescribes 18 years as the age of majority for both men and women. However for a person for whom a court has appointed a guardian and for a person whose property is under the superintendence of a court of wards, the age of majority is 21 years. The Act, however exempts from its purview the 'capacity' of a person to act in certain matters, including marriage. ${ }^{69}$ Thus the statutory age of majority does not determine the age of marriage.

\section{Registration of Marriage}

In India there is no central legislation requiring compulsory registration of marriage. Registration of marriage is compulsory only in four States of Maharashtra, Karnatka, Himachal Pradesh and Andhra Pradesh. In five States including Assam, Bihar, West Bengal, Orissa and Meghalaya, provisions have been made for voluntary registration of Muslim marriage. Provisions for compulsory registration of marriage have also been made under Special Marriage Act, 1954; Indian Christian Marriage Act, 1872; The Parsi Marriage and Divorce Act, 1936 and the Law of Marriage of Goa, Daman and Diu. Under Hindu Marriage Act, 1955 which is applicable to more than $80 \%$ of Indian population, registration of marriage is not compulsory. Recently, the matter was brought before the Supreme Court of India ${ }^{70}$ which made various directions to the Central government to take the required steps for the compulsory registration of marriage. The Law Commission of India has also, recently, recommended that the registration of marriages within a stipulated period, of all communities, should be made mandatory by the Government. $^{71}$

\footnotetext{
$69 \quad$ Indian Majority Act, 1875, S. 3.

$70 \quad$ Seema v Ashwani Kumar, (226) 2 SCC 578.

71 Government of India, Law Commission of India, Proposal to Amend The Prohibition of Child Marriage Act, 2006 and other Allied Laws, Report No. 205, 44, (2008).
} 


\section{The Special Marriage Act, 1954}

As regards civil marriages, The Special Marriage Act, 1954 makes provision for two types of marriages. One, those originally solemnized under its provisions and two, those originally solemnized under a personal law but later registered under it. In the case of first type of marriage, the girl and the boy are required to have completed, at the time of marriage, the age of 18 and 21years respectively. ${ }^{72}$ Regarding the latter type of civil marriage both parties are required to have attained, at the time of registration, the age of 21 years (irrespective of what their age was at the time of original solemnization of marriage).$^{73}$ Further, the consequences of the violation of age requirement for the two types of civil marriages are not same. In the case of a civil marriage originally solemnized under the Special Marriage Act, if it is found that either party was below the required age, the marriage is void and may be declared null and void by a decree of nullity to be passed by the court on a petition presented by either party to the marriage. ${ }^{74}$ As regards the marriage which originally solemnized under the personal law, is later registered under the Act of 1954, if it is found that at the time of registration either party was in fact below the age of 21 years, its registration under the Special Marriage Act, would be nullified, but the marriage would stand and be governed by the personal law under which it was initially solemnized. ${ }^{75}$ An under-age civil marriage that is null and void under the Special Marriage Act, 1954 would also attract penalty under the Child Marriage Restraint Act.

\section{Personal Laws}

\section{Hindu Law}

In 1955, the Indian Parliament enacted the Hindu Marriage Act, which is made applicable to any person who is Hindu, Buddhist, Jain or

\begin{tabular}{ll}
\hline 72 & Special Marriage Act, 1954, S. 4(c). \\
73 & Ibid., S. 15(d). \\
74 & Ibid., S. 24(1). \\
75 & Ibid., S. 24(2).
\end{tabular}


Sikh by religion. ${ }^{76}$ One of the conditions for solemnization of marriage prescribed by this Act was that the bridegroom should have attained the age of 18 years and the bride that of 15 years at the time of marriage. ${ }^{77}$ It also contained a provision to the effect that if the girl is in the age group of 15-18, then the guardian's consent for her marriage must be obtained. ${ }^{78}$ As regards the violation of these rules, the Act prescribed certain penalties. The punishment prescribed for the person who being under-age procured the solemnization of his or her marriage was simple imprisonment up to 15 days or fine up to Rupees 1000 or both. ${ }^{79}$ The person violating the requirement of parental consent where applicable, was made liable to a fine of up to Rupees $1000 .{ }^{80}$ However non-compliance with the age requirement or the guardian's consent did not render the marriage either void or voidable. During the course of the major changes made in 1976 to the Hindu Marriage Act, a new ground of divorce was added $^{81}$ whereby those girls who were given in marriage while they were below the age of 15 years were enabled to seek a divorce on the ground of under-age. This they could do at any time during three years following completion of the fifteenth year of age, even if the marriage was consummated.$^{82}$ Later on with the amendment of Child Marriage Restraint Act in 1978, the Hindu Marriage Act was also amended raising the age of marriage to 18 years for girls and 21 years for boys. It also abolished the requirement of parental consent for girls which after raising the age of marriage to 18 years for girls became superfluous. However no change had been introduced in the penal clause relating to marriage age. Moreover, like Child Marriage Restraint Act, the Hindu Marriage Act was also silent on the question of the nature of marriage solemnized in contravention of age requirement. It speaks nothing as to the validity or invalidity of such marriage. No reference to under-age marriage is

\footnotetext{
$76 \quad$ Hindu Marriage Act, 1955, S. 2.

77 Ibid., S. 5 (iii) original version.

$78 \quad$ Ibid., S. 5 (vi) (repealed in 1978).

79 Ibid., S.18(a).

$80 \quad$ Ibid., S. 18 (c).

81 See Ibid., S. 13 (2) (iv).

82 This was introduced in Hindu Marriage Act in accordance with one of the recommendations made in 1975 by the Committee on the Status of Women, 1975. See Government of India, Towards Equality: Report of the Committee on the Status of Women 113 (1975).
} 
made either under 'void marriage' ${ }^{83}$ or voidable marriage' ${ }^{84}$ defined under the Act. Consequently, the nature of such marriage has been a matter of controversy among various High Courts.

Before 1975, the various High Courts have taken the view that a Hindu marriage contrary to the law relating to age requirement is neither void nor voidable, but only punishable. ${ }^{85}$ In 1975 , for the first time in the history of social reform in India a religious marriage in violation of the statutory requirement as to the age of the parties was declared to be null and void ${ }^{86}$ by a Division Bench of Andhra Pradesh High Court ${ }^{87}$ The Court opined that if the contention, that by reason of the fact that sections 11 and 12 of Hindu Marriage Act do not at all provide for annulment of a marriage solemnized in contravention of age requirement prescribed by clause (iii) of section 5, is accepted: "it will throw open once again the flood gates of child marriages." 88 The object of Hindu Marriage Act, the court emphasized, is to prevent and eradicate the evil of child marriage. It ruled that for a child marriage even a decree of nullity would not be required since it would be a nullity in itself. However, two years later the Full Bench of the same High Court ${ }^{89}$ has overruled this Division Bench decision. The Full bench held that any marriage solemnized in contravention of clause (iii) of section 5 is neither void nor voidable, the only consequence being that the persons responsible are liable for punishment.

\section{Muslim Law}

In India, Muslims are governed by the uncodified Islamic law. Every Muslim of sound mind who has attained majority can enter into a

\begin{tabular}{ll}
\hline 83 & Ibid., S. 11. \\
84 & Ibid., S. 12. \\
& See Ms Kalawati v Devi Ram, AIR 1961 AP 1; Smt Nauni v Narotam, \\
& AIR 1963 HP 15; Ms Premi v Daya Ram; AIR 1965 HP 15; Ms Ma Hari \\
& v Director of Consolidation, 1969 All LJ 623; Budhi Sahu v Sahuni, \\
& ILR 1970 Cut 1215. \\
& Tahir Mahmood, “Marriage Age in Hindu Law, a Remarkable Decision \\
& from AP,” 2 Kurukshetra Law Journal, 163 (1976). \\
& P.A. Saramma v Ganapatulu. AIR 1975 AP 193. \\
87 & Ibid., at 195. \\
& P.V. Venkatraman v State, AIR 1977 AP 43 (FB).
\end{tabular}


contract of marriage. Majority is attained at puberty. The presumption is that a person attains majority at the age of 15 years unless proved otherwise. ${ }^{90}$ The marriage for minors can also be contacted but only by their guardians. A pre-puberty marriage is not invalid; but is voidable at the option of the minor which the minor can exercise on attaining puberty. This is called 'option of puberty.' The option when available is to be exercised soon after attaining puberty and before the consummation of marriage. ${ }^{91}$ However, under the Dissolution of Muslim Marriage Act, 1939 option of puberty can be exercised only by the girl. A girl married by a guardian before she attained the age of 15 years has a right to repudiate such marriage before attaining the age of eighteen years, if the marriage has not been consummated. ${ }^{92}$

\section{Christian Law}

As far as Indian Christians are concerned the Indian Christian Marriage Act, 1872 prescribed the marriage age of 13 years for girls and 16 years for boys. It further provided that where the party to the marriage was below the age of 18 years, parents or guardian's consent would be required.$^{93}$ In 1952, the age of marriage was raised to 15 years for girls and 18 years for boys. ${ }^{94}$ The Child Marriage Restraint (Amendment) Act, 1978 has further amended the Christian marriage Act of 1872. Now the age of marriage under the Act is 18 years for girls and 21 years for boys, and the requirement for parental consent has been abolished. ${ }^{95}$

\footnotetext{
$90 \quad$ A.A.A. Fayzee, Outlines of Muhammadan Law, 73 (2008).

91 Tahir Mahmood, The Muslim Law of India, 48-54 (1980).

92 Dissolution of Muslim Marriage Act, 1939, S. 2 (vii).

$93 \quad$ Indian Christian Marriage Act, 1872, S 60 (original version). Act XLVIII of 1952 amended s. 60 of Indian Christian Marriage Act, 1872.

$95 \quad$ S. 60 as amended in 1978, proviso to s. 60 deleted in 1998. The Christain Marriage Act does not apply in the States of Jammu and Kashmir and Manipur and in the Tranvancore-Cochin areas of the State of Kerala. See S. 1 of the Act. In Jammu and Kashmir the Christian Marriage and Divorce Act, 1901 is in force under which the age of marriage is same as under the original version of Christian Marriage Act, 1872.However it applies subject to the provisions of the local Infant marriage
} 
The violation of age requirement does not render the marriage invalid under the Act.

\section{Parsi Law}

Parsis in India, in the matter of marriage were governed by the Parsi Marriage and Divorce Act, 1865, which did not fix any marriageage. It, however required persons of either sex below the age of 21 years to marry only with parental consent; without it their marriage would be invalid. In 1936, the Act of 1865 was replaced by a new The Parsi Mariage and Divorce,1936, under which the marriage age provisions were the same. ${ }^{96}$ By the Amendment Act of 1988 this provision has been substantially amended. ${ }^{97}$ Now as far as the boy is concerned, the age of 21 years is retained but for the girl it is brought down to 18 years. Further the requirement as to guardian's consent has also been abolished. Like other personal laws, Parsi law also does not render under-age marriage invalid.

\section{RELIGION VIS-À-VIS NATIONAL LEGAL SYSTEMS}

The relationship of religion and law has been changing with the changing time. Centuries have intervened between the old times when religion fully controlled the law and the present new age where the two social-control mechanisms have exchanged their positions. ${ }^{98}$ Religion now has to operate within the parameters set by international human-rights conventions, national constitutions and other domestic laws, and judicial interpretation of rights embodied in these documents.

\footnotetext{
Prevention act, 1928 of that state. In Manipur and Travancore there is no statutory law of marriage for Christians and in the absence of such a law it is not clear which law applies. Tahir Mahmood, supra $\mathrm{n} 91$ at 60 . 96 The Parsi Mariage and Divorce,1936, S. 3 (c); also see SS. 6, 38 (before amendment of 1988).

$97 \quad$ Act No. 5 of 1988.

98 Tahir Mahmood, Laws of India on Religion and Religious Affairs, 2, (2008).
} 
Going by the present-day constitutional documents of various countries, one finds three different models of religion-state relations operating in various countries. The First Model is that in which a particular religious faith is either recognized as the State religion or otherwise given a prime position by the Constitution and the basic laws. The Second is in which there is no official religion and the State has no constitutionally assigned or legally sanctioned role to play in religious affairs. In the Third Model, there is no officially adopted State religion but the State plays a legally permissible role in the affairs of religion. ${ }^{99}$ Adopting the First Model of religion-state relations, Bhutan and Sri Lanka confer a special status on Buddhism. In Bhutan the Preamble ${ }^{100}$ of the Constitution of 2005 refers to the country as a land 'Blessed with the luminous benedictions of the Triple Gem and the protection of our guardian deities'-the 'Triple Gem' meaning the Buddha, Dharma and Sangha of the Buddhist religious tradition. The Constitution further declares Bhutan to be a 'country of Chhoe-sid' and Buddhism as its 'Spiritual heritage,' empowering the king to constitute a supreme religious body, the Dratshang Lhentshog, to supervise Buddhist religious affairs. ${ }^{101}$ The National Anthem of Bhutan incorporated in the Constitution in Schedule II opens with the words 'As the Doctrine of the Lord Buddha flourishes, may the Sun of peace and happiness shine on the people.'

In Sri Lanka, the Constitution of 1997 proclaims that 'Sri Lanka shall give to Buddhism the foremost place and accordingly it shall be the duty of the State to protect and foster the Buddha Sasana (Buddhist Social order); it shall provide for the establishment of a supreme religious Council called the Maha Sangha. ${ }^{102}$

In Nepal successive Constitutions including that of 1990 described the country as a 'Hindu Monarchical Kingdom' and the King as ‘an

\footnotetext{
$99 \quad$ Ibid., at 3.

100 The Constitution of Bhutan, 2005, Preamble available at www.constitution.bt/html/constitution/preamble.htm visited on March 5, 2010.

101 Ibid., Article 3 available at www.constitution.bt/html/constitution/ articles.htm visited on March 5, 2010.

102 The Constitution of the Democratic Socialist Republic of Sri Lanka,1978, Article 9, available at www.priu.gov.lk/cons/ 1978constitution/chapter_02_Amd.html visited on March 5, 2010.
} 
adherent of Aryan culture and the Hindu religion ${ }^{103}$ Recent trends in Nepal favor a secular state and the country is now in a stage of transition. Change of religion is not possible in Nepal, as conversion from one religion to any other religious faith is prohibited by the Interim Constitution of Nepal, 2007. ${ }^{104}$ The Constitution of Maldives declares that the religion of the State of Maldives is Islam. It further declares that Islam shall be one of the basis of all the laws of the Maldives. No law contrary to any tenet of Islam shall be enacted in Maldives. ${ }^{105}$ The Afghanistan Constitution of 2004, besides declaring the country to be an Islamic Republic and Islam to be the State religion, says that 'no law can be contrary to the beliefs and provisions of the sacred religion of Islam' 106 The Pakistan Constitution of 1973 besides declaring the country as an Islamic Republic and Islam as the State religion, pronounces that 'all existing laws shall be brought in conformity with the injunctions of Islam.' ${ }^{107}$ The Bangladesh Constitution of 1972. as amended, proclaims that 'State religion of the Republic is Islam but other religions may be practiced in peace and harmony in the republic.' ${ }^{108}$ The most conspicuous example of the third model of religion-state relations-in which there is no official or privileged religion but the State has a role to play in religious affairs of all communities is the Republic of India. ${ }^{109}$

Interim Constitution of Nepal, 2063 (2007), Article 4 available at www.worldstatesmen.org/Nepal_Interim_constitution2007.pdf visited on March 5, 2010.

Ibid., Article 23.

Functional translation of the Constitution of the Republic of Maldives, 2008, Article 10, available at www.presidencymaldives.gov.mv/ publications/constitution.pdf visited on March 5, 2010.

The Constitution of Afghanistan, 2004, Chap 1, Articles 2 and 3, available at www.president.gov.af visited on March 5, 2010.

The Constitution of the Islamic Republic of Pakistan, 1973, Article 2 available at www.pakistani.org/pakistan/constitution/ visited on March, 5, 2010.

The Constitution of the people's Republic of Bangladesh, 1972,Article 2-A available at www.pmo.gov.bd/constitution/index.htm visited on March, 5, 2010.

The Constitution of India, 1950, available at http://indiacode.nic.in/ coiweb/welcome.html visited on March 5, 2010. 


\section{CONCLUSION}

We have seen that all the South Asian countries studied herein, have laws prescribing the age of marriage. Sri Lanka, Maldives, and Bhutan have set the minimum age of marriage at 18 years which applies equally to both boys and girls. The general rule in Bangladesh, Nepal and India is that the girl must have attained the age of 18 years and the boy 21 years. In Afganistan and Pakistan girls can marry at the age of 16 years but a different standard applies to boys who need to be 18 years old. In Sri Lanka and Bangladesh Muslim law allows girls to be given away in marriage once they attain puberty.

Many South Asian countries have inherited a plural legal system as a legacy of colonialism. While the constitutional provisions of these countries vary widely: some being democratic and secular and others theocratic in the sense that they proclaim State religion, their colonial legacy ensure that they inherited the common problem of plural legal systems: one secular legal system dealing with public domain and the other system dealing with the private domain, consisting manly of family laws. ${ }^{110}$ The time has come, however, to recognize that child marriage affects the public at large and is not a private arrangement between two persons or two families. The false dichotomy of private/public spheres cannot obscure the way in which marriage can affect a girl child's civil, political, economic, social and cultural rights.

The lives of women in South Asian counties are still regulated more by custom, traditions and religious beliefs than by enacted laws. This is also one of the reasons that child marriage though prohibited by law is still prevalent. However, despite religious and cultural values, child marriage has to be eradicated from the society. The State is responsible for customs and traditions that violate the rights of children and women. However, in any society, where the majority of population is illiterate, ignorant and backward, age-old customs are not easy to do away with. Education spreading awareness among the people, about the adverse consequences of child marriage, particularly in rural areas can be very useful. When people, especially women are made aware of their own rights and the rights of their children, they will be able to ensure the rights of their children. Though, laws are not the only means to remove 
child marriage from society, nonetheless, they are effective means in combating it. These laws should be well defined. An enforcement mechanism should be developed to ensure effective implementation of the law.

In Sri Lanka, where age at marriage has traditionally been low, average age for marriage is now 25 years. The country's success in raising marriage age has been driven by the introduction of legislative reforms requiring all marriages to be registered and the consent of both marriage partners be recorded. Moreover, Sri Lankan courts have ruled that specific cases of non-consensual marriages arranged by parents on behalf of their children are invalid. The positive impact of legislative changes have been supported by social policies on health and education, including free education from primary to university level, to create an environment in which the practice of early marriage is in steep decline. ${ }^{111}$ In Maldives, the number of early marriages is constantly declining. Improved access to secondary education and more employment opportunities appear to have a positive impact on the age at marriage. ${ }^{112}$

In 2002, the South Asian countries adopted the SAARC Convention on Regional Arrangement for the Protection of Child in South Asia. Another important instrument that contributes towards improving the status of the girl child is the SAARC Social Charter signed at the twelfth Summit held in 2004. The South Asian Countries have ratified the conventions related to the rights of the child, their protection and well-being like CRC, CEDAW, and Convention on Minimum Age for Marriage, Consent to Marriage, Registration of Marriage etc. The Convention on Minimum age for marriage makes the registration of marriages compulsory. It enjoins the states to eliminate child marriages and betrothal of young girls and to provide appropriate penalties for transgression. Only very few South Asian Countries, however, have made registration of marriages compulsory. Further, the enactments prescribing minimum age of marriage in most of the South Asian countries are weak, the punishment provided therein is lenient and above all they make underage marriage only illegal and not invalid, except Sri Lanka which has made such marriage void in 1995. Perspective, UNICEF-ICDC, 117 and 324 (1998). 
Recently, in India, The Prohibition of Child Marriage Act 2006 has been passed which, incorporates some effective provisions to combat child marriages. It declares child marriage under certain circumstances as null and void. ${ }^{113}$ In all cases, child marriage is voidable at the option of the contracting party to the marriage, who was child. In case of annulled viodable marriage, it makes provisions for the maintenance and residence for the girl child until her remarriage. For the proper implementation of the Act, it provides for the appointment of Child Marriage Prevention officers and also empowers the courts to issue injunctions prohibiting the solemnization of child marriage. All offences under the Act are made cognizable. Penalty provisions for solemnizing or promoting a child marriage are also strict. It provides for rigorous imprisonment and fine. However no woman can be punishable with imprisonment. Thus PCMA is gender sensitive and is built up on human rights agenda incorporating the feminist perspective in various provisions of the Act.

The States are responsible for enforcing the international human rights law. The international law of State responsibility for human rights violation which is of recent origin aims to ensure that States comply with their obligations which they have accepted by ratifying the international human rights treaties, and thus prevent future violation of human rights. The child marriage performed by the individuals does not necessarily implicate the State. However, when the State tolerates or excuses child marriage by not prosecuting those who are responsible for contracting child marriages, the State bears the responsibility, as marriage is a state -sanctioned institution. The State is responsible not directly for contracting child marriages, but for its own lack of diligence in preventing through its executive, legislative, or judicial organs the private act of contracting child marriage. The State is also responsible because child marriage violates specific human rights that are binding on the State as a matter of international law. The responsibility of States is not only that they themselves should not violate human rights but that they should meet international obligations to deter and condemn such violations perpetrated by private persons. ${ }^{114}$ The State is accountable for the customs and beliefs

\footnotetext{
$113 \quad$ See supra n. 67.

$114 \quad$ Rebecca Cook, "State Accountability under the Convention on the Elimination of Discrimination against Women,” in Rebecca Cook (ed.) supra n. 12 at 228 (238).
} 
of people that violate the panoply of interconnected rights of the girl child. Child marriage does not exist in isolation but coexist with gender in equitable provisions in other areas of public, secular and private laws. ${ }^{115}$ Legal strategy must therefore be a holistic process, outlawing all areas of gender inequity in order to combat child marriage.

$115 \quad$ United Nations Children’s Fund, Supra n. 8 at 37. 